\title{
Diverse Mechanisms Underlie Glycinergic Feedback Transmission onto Rod Bipolar Cells in Rat Retina
}

\author{
Andrés E. Chávez and Jeffrey S. Diamond \\ Synaptic Physiology Section, National Institute of Neurological Disorders and Stroke, National Institutes of Health, Bethesda, Maryland 20892-3701
}

Synaptic inhibition shapes visual signaling in the inner retina, but the physiology of most amacrine cells, the interneurons that mediate this inhibition, is poorly understood. Discerning the function of most individual amacrine cell types is a daunting task, because few molecular or morphological markers specifically distinguish between approximately two dozen different amacrine cell types. Here, we examine a functional subset of amacrine cells by pharmacologically isolating glycinergic inhibition and evoking feedback IPSCs in a single cell type, the rod bipolar cell (RBC), with brief glutamate applications in the inner plexiform layer. We find that glycinergic amacrine cells innervating RBCs receive excitatory inputs from $\mathrm{ON}$ and OFF bipolar cells primarily via NMDA receptors (NMDARs) and $\mathrm{Ca}^{2+}$-impermeable AMPA-type glutamate receptors. Glycine release from amacrine cells is triggered by $\mathrm{Ca}^{2+}$ influx through both voltage-gated $\mathrm{Ca}^{2+}\left(\mathrm{Ca}_{\mathrm{v}}\right)$ channels and NMDARs. These intracellular $\mathrm{Ca}^{2+}$ signals are amplified by $\mathrm{Ca}^{2+}$-induced $\mathrm{Ca}^{2+}$ release via both ryanodine and $\mathrm{IP}_{3}$ receptors, which are activated independently by $\mathrm{Ca}^{2+}$ influx through $\mathrm{Ca}_{\mathrm{v}}$ channels and NMDARs, respectively. Glycinergic feedback signaling depends strongly, although not completely, on voltage-gated $\mathrm{Na}^{+}$channels, and the spatial extent of feedback inhibition is expanded by gap junction connections between glycinergic amacrine cells. These results indicate that a diversity of mechanisms underlie glycinergic feedback inhibition onto RBCs, yet they highlight several physiological themes that appear to distinguish amacrine cell function.

Key words: amacrine; AMPA receptor; $\mathrm{Ca}^{2+}$-induced $\mathrm{Ca}^{2+}$ release; calcium channels; feedback; gap junction; glutamate receptor; glycine; interneuron; retina; retinal bipolar cell

\section{Introduction}

Visual signals in the inner retina are shaped by synaptic inhibition mediated by amacrine cells, a diverse class comprising approximately two dozen individual cell types (Kolb and Nelson, 1981; MacNeil and Masland, 1998). About one-half of these amacrine cell types release glycine as their primary neurotransmitter (Pourcho and Goebel, 1985, 1987; MacNeil and Masland, 1998; Menger et al., 1998), but the function of most glycinergic amacrine cells is poorly understood. The most common and thoroughly studied glycinergic amacrine cell, the AII, relays synaptic input from ON rod bipolar cells (RBCs) to ON and OFF cone bipolar cell terminals via gap junctions and inhibitory glycinergic synapses, respectively (Kolb and Nelson, 1983; Dacheux and Raviola, 1986; Strettoi et al., 1990), and also inhibits OFF ganglion cells directly (Murphy and Rieke, 2008). AIIs do not make reciprocal feedback synapses onto the same RBCs that excite them (Kolb and Nelson, 1983; Dacheux and Raviola, 1986; Ster-

Received Feb. 21, 2008; revised June 18, 2008; accepted June 20, 2008.

This work was supported by the National Institute of Neurological Disorders and Stroke Intramural Research Program. We thank Wei Li, Annalisa Scimemi, and Will Grimes for comments on this manuscript and David Paul for kindly providing the Connexin $36-/-$ mice.

Correspondence should be addressed to Dr. Jeffrey S. Diamond, Synaptic Physiology Section, National Institute of Neurological Disorders and Stroke, National Institutes of Health, 35 Convent Drive, Building 35, Room 3C-1000, Bethesda, MD 20892-3701. E-mail: diamondj@ninds.nih.gov.

A. E. Chávez's present address: Department of Neuroscience, Albert Einstein College of Medicine, Bronx, NY 10461.E-mail:achavez@aecom.yu.edu.

DOI:10.1523/JNEUROSCI.0784-08.2008

Copyright $\odot 2008$ Society for Neuroscience $\quad$ 0270-6474/08/287919-10\$15.00/0 ling and Lampson, 1986). RBCs do, however, express functional glycine receptors in their axons and synaptic terminals (Suzuki et al., 1990; Gillette and Dacheux, 1995) and receive lateral feedback from glycinergic amacrine cells activated by other bipolar cells in the retinal circuitry (Cui et al., 2003; Eggers and Lukasiewicz, 2006a; Ivanova et al., 2006) that regulates their synaptic output (Eggers and Lukasiewicz, 2006b). The characteristics of the amacrine cells providing this lateral glycinergic feedback have not been investigated.

Glycinergic amacrine cells generally exhibit compact dendritic arbors that rarely extend $>100 \mu \mathrm{m}$ laterally through the inner plexiform layer (IPL) (Kolb and Nelson, 1996; MacNeil and Masland, 1998; Menger et al., 1998). In most glycinergic amacrine cells, the morphological segregation between synaptic inputs and outputs is unclear, and the mechanisms underlying the transformation of excitatory glutamatergic input to glycine release are primarily unknown. Although adjacent input and output regions theoretically could interact via passive electrotonic depolarization, feedforward glycinergic transmission (i.e., from amacrine cells to ganglion cells) is partially dependent on tetrodotoxin (TTX)-sensitive voltage-gated $\mathrm{Na}^{+}\left(\mathrm{Na}_{\mathrm{v}}\right)$ channels (Protti et al., 1997; Cook et al., 1998; Bieda and Copenhagen, 1999), as is glycinergic feedback onto RBCs (Cui et al., 2003). It is unknown in glycinergic amacrine cells whether the input-output transformation is enhanced by $\mathrm{Ca}^{2+}$-induced $\mathrm{Ca}^{2+}$ release (CICR) from intracellular stores. Additionally, it remains uncertain whether RBCs receive immediate reciprocal feedback from 
glycinergic amacrine cells that they contact (Kolb and Nelson, 1996).

Here, we address these issues in rat and mouse retinal slices by recording glycinergic postsynaptic currents in RBCs elicited by pharmacological stimulation of amacrine cells in the IPL or bipolar cells in the outer plexiform layer (OPL). We find that amacrine cells that release glycine onto RBCs receive excitatory synaptic input from $\mathrm{ON}$ and/or OFF bipolar cells via multiple glutamate receptor subtypes, boost dendritic signaling with $\mathrm{Na}_{\mathrm{v}}$ channels, and expand the spatial extent of feedback through gap junction connections. $\mathrm{Ca}^{2+}$ influx that triggers glycine release enters via voltage-gated $\mathrm{Ca}^{2+}\left(\mathrm{Ca}_{\mathrm{v}}\right)$ channels and NMDA receptors (NMDARs), and these distinct inputs are amplified separately by different CICR pathways. These results indicate that amacrine cells use a complex combination of mechanisms to coordinate synaptic inputs and outputs in their dendritic arbors.

\section{Materials and Methods}

Retinal slices (210 $\mu \mathrm{m}$ thick) were prepared from Sprague Dawley rats [postnatal day 17 (P17) to P23] and C57BL/6 mice [P17-P21; wild type and Connexin36 -/ - (Cx36-/-)] (Deans et al., 2002) using previously described methods (Singer and Diamond, 2003; Chavez et al., 2006). Briefly, retinas were isolated and maintained in artificial CSF (ASCF) containing (in mM) $119 \mathrm{NaCl}, 26 \mathrm{NaHCO}_{3}, 1.25 \mathrm{Na}_{2} \mathrm{HPO}_{4}, 2.5 \mathrm{KCl}, 2.5$ $\mathrm{CaCl}_{2}, 1.5 \mathrm{MgSO}_{4}, 10$ glucose, $2 \mathrm{Na}$-pyruvate, and $4 \mathrm{Na}$-lactate, equilibrated with $95 \% \mathrm{O}_{2} / 5 \% \mathrm{CO}_{2}$. Slices were placed beneath a $40 \times$ waterimmersion lens on a fixed-stage microscope (Zeiss Axioskop 2) and visualized using infrared differential interference contrast (DIC) video microscopy. RBCs were distinguished from other bipolar cells by their goblet-shaped somata located in the outer portion of the inner nuclear layer (INL), immediately adjacent to the OPL (Fig. $1 A$ ). In many experiments $(n=173)$, recordings were made with Alexa- 488 hydrazide ( 50 $\mu \mathrm{M}$ ) added to the patch solution (Fig. $1 A$ ), allowing morphology to be confirmed at the end of the experiment. In nearly 98\% (169 of 173) of these cases, the filled cell exhibited typical RBC morphology, extending a single axon through the INL and IPL that terminated in a small cluster of swelled branches in the innermost portion of the IPL (Fig. 1 A) (Euler and Wässle, 1995; Hartveit and Veruki, 1997; Protti and Llano, 1998; Singer and Diamond, 2003). This morphology was distinct from that of cone bipolar cells (Fig. 1 B) (Ivanova et al., 2006).

Whole-cell patch-clamp recordings (Axoclamp-1D; Molecular Devices) were made while continuously superfusing the slice with ASCF at a rate of $1-2 \mathrm{ml} / \mathrm{min}$. Patch electrodes $(8-11 \mathrm{M} \Omega$ ) contained (mM) $100 \mathrm{Cs}$ methanesulfonate, 20 tetraethylammonium-Cl, 10 HEPES, 1.5 BAPTA, $10 \mathrm{Na}$ phosphocreatine, $4 \mathrm{Mg}$-ATP, $0.4 \mathrm{Na}-\mathrm{GTP}$, and 10 glutamic acid, pH 7.4. RBCs exhibited high-input resistances ( $1.9 \pm 0.8 \mathrm{G} \Omega$; $n=233)$.

All experiments, except where indicated, were performed at room temperature in ACSF supplemented with the specific $\mathrm{GABA}_{\mathrm{A}}$ and $\mathrm{GABA}_{\mathrm{C}}$ receptor antagonists, 6-imino-3-(4-methoxyphenyl)-1(6H)pyridazinebutanoic acid hydrobromide (SR95531; $10 \mu \mathrm{M})$ and 1,2,5,6tetrahydropyridine-methylphosphonic acid (TPMPA; $50 \mu \mathrm{M}$ ), respectively. In some experiments, the ASCF contained $50 \quad \mu \mathrm{M}$ 5,7dihydroxytryptamine (DHT), a neurotoxic serotonin analog that ablates A17 amacrine cells and eliminates GABAergic reciprocal feedback (Dong and Hare, 2003; Chavez et al., 2006). Drugs were bath applied at a rate of 1-2 $\mathrm{ml} / \mathrm{min}$ for 5-10 $\mathrm{min}$ after establishment of a stable baseline ( $\sim 10-15$ responses), and their effects were measured after responses reached a new steady state (usually $<5 \mathrm{~min}$ ) (Fig. $1 \mathrm{D}$ ). Some drugs [e.g., metabotropic glutamate receptor ( $\mathrm{mGluR}$ ) antagonists] required slightly longer application times ( $\leq 13 \mathrm{~min}$ ). Cells that exhibited significant rundown $(\geq 10 \%)$ before drug application were discarded. Reagents were obtained from Sigma or Tocris, except TTX (Alomone Labs), Alexa-488 (Invitrogen), and 1-(4-aminophenyl)-3-methylcarbamyl-4-methyl-3,4dihydro-7,8-methylenedioxy-5H-2,3-benzodiazepine (GYKI 53655; a gift from Dr. J. Isaac, National Institute of Neurological Disorders and Stroke, National Institutes of Health, Bethesda, MD).

Puffed agents were applied using a Picospritzer II (General Valve)
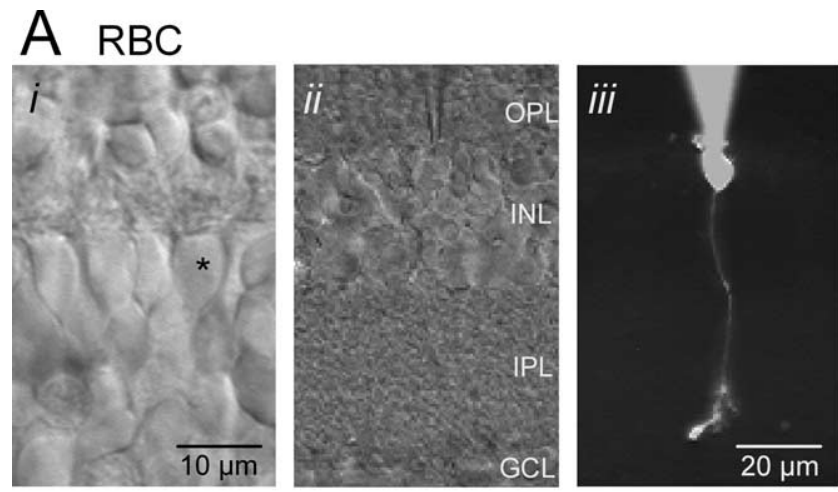

\section{$\mathrm{B} \mathrm{CBC}$}
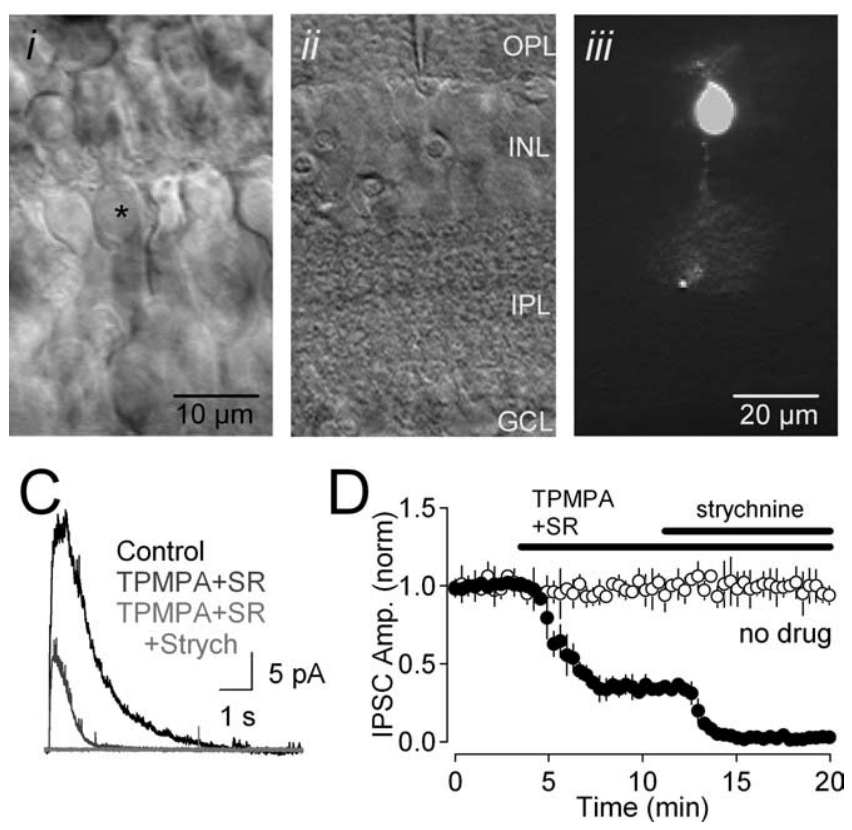

Figure 1. Whole-cell recordings of inhibitory feedback in RBCs in retinal slices. $\boldsymbol{A}$, Micrographs of an RBC in a retinal slice. $\boldsymbol{i}$, High-magnification DIC image of the INL, showing bipolar cell somata. ii, iii, The selected cell (*) was patched (ii), filled with Alexa-488, and imaged under epifluorescence (iii). The scale bar in iii also applies to ii. $\boldsymbol{B}$, As in $\boldsymbol{A}$, but recording from a cone bipolar cell (CBC). C, Feedback IPSCs elicited in an $\mathrm{RBC}\left(V_{\text {hold }}=0 \mathrm{mV}\right)$ were blocked partially by GABAR antagonists TPMPA and SR95531 (SR); the remaining IPSC was blocked by the glycine receptor antagonist strychnine (Strych). D , Time course of drug effects on IPSC amplitude (filled circles; $n=4)$. IPSC amplitude (IPSC Amp.) remained stable in the absence of applied drugs (open circles; $n=4$ ). GCL, Ganglion cell layer.

connected to a patch pipette (resistance, $\sim 8-10 \mathrm{M} \Omega$ ). The tip of the puffer pipette was positioned at various locations within the $x y$ plane of the slice, according to the requirements of the particular experiment; in the $z$-axis, it was positioned just beneath $(\leq 20 \mu \mathrm{m})$ the surface of the slice. The puffing solution was identical to control ACSF, except that it contained the stimulating agent [e.g., glutamate, $(R S)$ - $\alpha$-cyclopropyl-4phosphonophenylglycine (CPPG), kainate, or caffeine] and was $\mathrm{pH}$ buffered with HEPES (10 mM). Applied alone, HEPES-buffered ACSF did not evoke any response in RBCs (data not shown). Except where indicated, $\mathrm{RBCs}$ were voltage clamped at $0 \mathrm{mV}$ (the reversal potential for excitatory inputs), and puff application of L-glutamate ( $50 \mu \mathrm{M}, 25 \mathrm{~ms}, 1$ bar $)$ in the innermost part of the IPL elicited synaptic glycinergic feedback IPSCs from amacrine cells onto RBCs. In some experiments (see Fig. 5), CPPG ( $600 \mu \mathrm{M}, 300 \mathrm{~ms}, 1.5$ bar) or kainate $(100 \mu \mathrm{M}, 300 \mathrm{~ms}, 1.5 \mathrm{bar})$ was puffed in the OPL (80-100 $\mu$ m laterally from the recorded RBC) to activate ON and OFF bipolar cells, respectively. In these experiments, control ACSF also contained the group III mGluR agonist L-AP-4 (10 $\mu \mathrm{M})$.

To measure the spatial extent of glycinergic amacrine cell input to the 

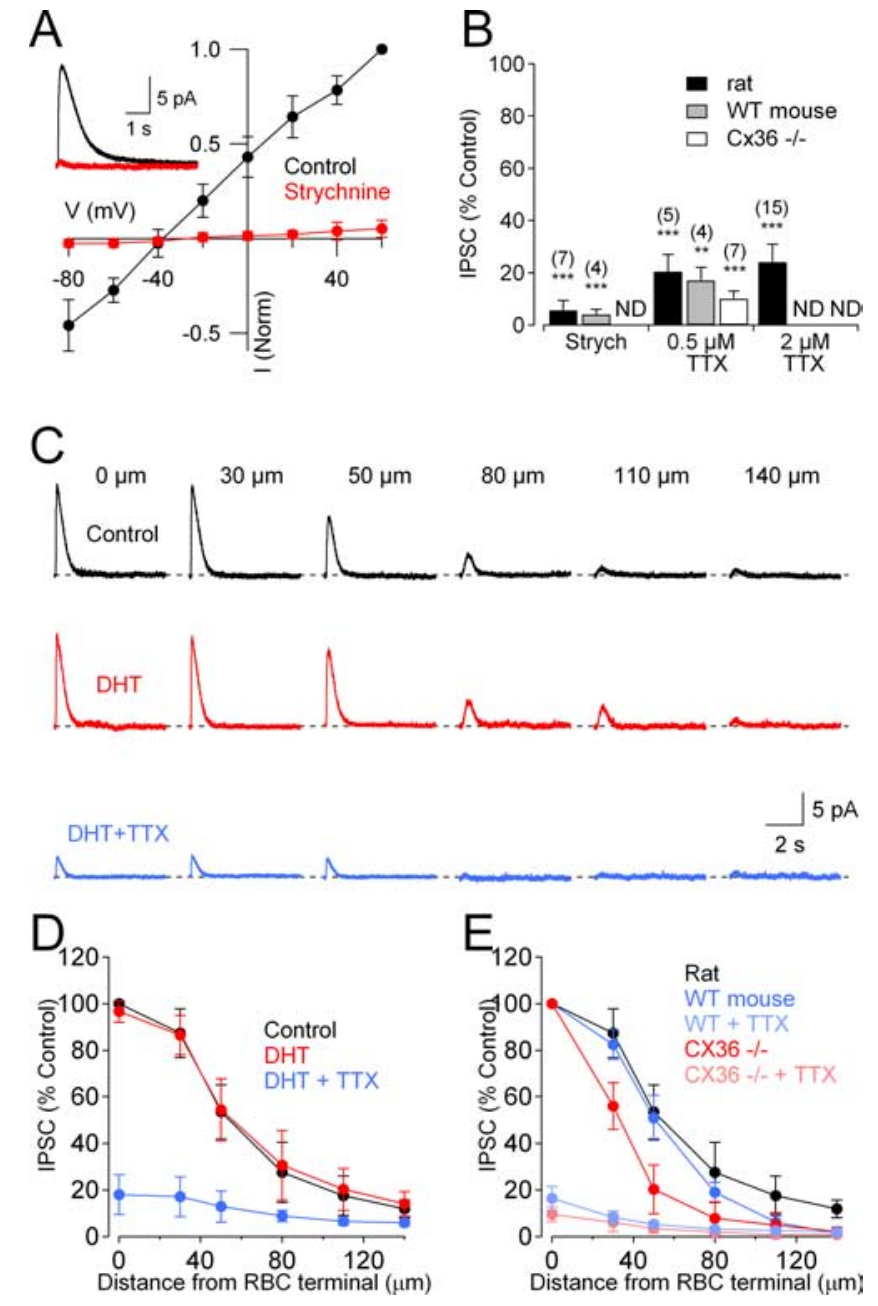

Figure 2. Gap junctions extend the lateral spread of glycinergic feedback onto RBCs. $\boldsymbol{A}$, Glycinergic IPSCs evoked in RBCs in the presence of GABAR antagonists were blocked by strychnine $(3 \mu \mathrm{M})$ and reversed close to $E_{\mathrm{Cl}}{ }^{-}$. Inset, IPSCs recorded in control solution and in the presence of strychnine. $\boldsymbol{B}$, Summarized drug effects (mean \pm SD) on IPSCS. ND, Experiment not done; Strych, strychnine. $C$, Glycinergic IPSCs evoked by glutamate puffed at different distances from the RBC were unaffected by DHT ( $50 \mu \mathrm{m}$; red traces) but reduced significantly by TTX ( 0.5 $\mu \mathrm{m}$; blue traces). $D$, Summary of the spatial distribution of IPSCs in the presence of DHT and TTX $(n=6)$. $\boldsymbol{E}$, Comparison of the spatial distribution of IPSCs in WT and $C \times 36-1-$ mice in the absence and presence of TTX $(2 \mu \mathrm{M})$.

RBC (Fig. $2 C-E$ ), the puff pipette was positioned initially at " $0 \mu \mathrm{m}$ " (i.e., centered directly above the terminal varicosities of the recorded RBC), filled with Alexa-488, and visualized under epifluorescence. After three responses at that position, the pipette was moved laterally in the IPL, and three responses were recorded at each position. At the end of each series, the pipette was returned to the $0 \mu \mathrm{m}$ position, and three final responses were averaged and compared with the $0 \mu \mathrm{m}$ responses obtained at the beginning of the experiment. If the final $0 \mu \mathrm{m}$ responses were $\geq 10 \%$ smaller than the initial responses, the data were not analyzed further. Peak response amplitudes at each position were normalized to that recorded at the initial $0 \mu \mathrm{m}$ position in control solution. The lateral extent of inhibition was quantified by reflecting the data (Fig. $2 D$ ) about the $y$-axis and fitting the symmetrical wave form to a Gaussian function:

$$
f(x)=A e^{\frac{-x^{2}}{2 \sigma^{2}}}
$$

The lateral extent of feedback then was expressed as the half width of the fit at half maximum (HWHM):

$$
H W H M=\sqrt{2 \ln 2 \sigma} .
$$

The spatial extent of the puff itself (supplemental Fig. 1, available at www.jneurosci.org as supplemental material) was quantified in the same way to facilitate comparison with the glutamate-evoked IPSC data.

Glycinergic feedback IPSCs were elicited at 14-20 s intervals, filtered at $2 \mathrm{kHz}$, and sampled at $10 \mathrm{kHz}$ by an ITC-18 analog-to-digital board (InstruTECH) controlled by software written in Igor Pro (Wavemetrics). Feedback IPSC amplitude was measured as the difference between the response peak and the baseline preceding stimulation. Unless indicated otherwise, statistical comparisons were made with a paired, two-tailed Student's $t$ test (Igor Pro), and significance was concluded when $p<0.05$. In the figures, ${ }^{*} p<0.05,{ }^{* *} p<0.01$, and ${ }^{* * *} p<0.001$, and the number of experiments $(n)$ is indicated in parentheses. Data are presented as mean $\pm \mathrm{SD}$, and illustrated traces are averages of 3-20 responses.

\section{Results}

Voltage-clamp recordings from $\mathrm{RBC}$ somata were made to examine the properties of glycinergic inhibition onto $\mathrm{RBC}$ axons and synaptic terminals in rat and mouse retinal slices (all illustrated responses were recorded in rat). Glutamate puffs in the IPL (see Materials and Methods) elicited IPSCs comprising GABAergic and glycinergic components (Fig. 1C,D). IPSCs were partially reduced by bath application of SR95531 $(10 \mu \mathrm{M})$ and TPMPA (50 $\mu \mathrm{M}), \mathrm{GABA}_{\mathrm{A}}$ and $\mathrm{GABA}_{\mathrm{C}}$ receptor antagonists, respectively (to $33 \pm 10 \%$ of control; $n=4 ; p=0.006$ ) (Fig. $1 C, D$ ). The remaining component (peak amplitude, $13 \pm 4 \mathrm{pA} ; n=167$; range, 7-36 $\mathrm{pA}$ ) was eliminated by the competitive glycine receptor antagonist strychnine ( $3 \mu \mathrm{M} ; n=11 ; p=0.006$ ) (Figs. $1 C, D, 2 A, B$ ). Glycinergic IPSCs were observed in every RBC tested. In all subsequent experiments, unless indicated otherwise, glycinergic IPSCs were isolated by including SR95531 and TPMPA in the bath solution. Glycinergic IPSCs reversed near the calculated chloride equilibrium potential $\left[E_{\mathrm{rev}}=-37.5 \pm 5.3 \mathrm{mV}\right.$ (uncorrected for an approximate $-10 \mathrm{mV}$ liquid junction potential); $n=6 ; E_{\mathrm{Cl}}=$ $-47 \mathrm{mV}$ ) (Fig. 2A).

\section{Spatial extent of glycinergic feedback is expanded by gap junctions}

Glycinergic amacrine cells typically extend narrow dendritic arbors into the IPL (lateral radius, $\leq 50 \mu \mathrm{m}$ ) (Kolb et al., 1981; Pourcho and Goebel, 1985; Menger et al., 1998). To determine the spatial extent of glycinergic feedback onto a single RBC, we moved the glutamate puffer pipette laterally within the inner part of the IPL to various distances from the RBC axon terminal (Fig. $2 C$ ). Feedback IPSC amplitude was gradually diminished as the puff pipette was moved away from the recorded RBC (Fig. 2C,D) $(n=5)$, but the spatial extent of the feedback inhibition (Gaussian half-width at half-maximum (HWHM), $51 \pm 8 \mu \mathrm{m} ; n=5$ ) (Fig. $2 D$ ) was greater than expected, given the narrow dendritic arbors ( $\leq 50 \mu \mathrm{m}$ lateral radius) of most glycinergic amacrine cells (Kolb et al., 1981; Pourcho and Goebel, 1985; Menger et al., 1998). Because many amacrine cell types are electrically coupled (Vaney, 1994), it is possible that a postsynaptic response could pass between amacrine cells through gap junctions, expanding the apparent area of the IPL over which feedback IPSCs may be elicited. To test this idea, the spatial extent of feedback inhibition was measured in wild-type (WT) mice and mice lacking the gap junction subunit Cx36-/- (Deans et al., 2002). Although deletion of $\mathrm{Cx} 36$ could cause compensatory changes in retinal circuitry, Cx36-/- retinas exhibit no differences in laminar organization or the number, size, and density of cell nuclei in all retinal layers (Guldenagel et al., 2001). Accordingly, glycinergic IPSCs in WT and Cx36- $/-$ slices exhibited similar peak amplitude (WT: $16 \pm 4 \mathrm{pA}, n=32$; Cx36-/-: $16 \pm 5 \mathrm{pA}, n=12 ; p=$ $0.97)$. The spatial extent of feedback in WT mice was similar to rat 
(Gaussian HWHM, $50 \pm 4 \mu \mathrm{m} ; n=5 ; p=0.93$ compared with rat) (Fig. $2 E$ ) but was significantly reduced in slices from Cx36-/- mice (Gaussian HWHM, $32 \pm 4 \mu \mathrm{m} ; n=8 ; p=$ 0.00006 compared with WT) (Fig. 2E).

The spatial resolution of the glutamate puff method was tested in rat slices by recording IPSCs while incrementally moving the puffer pipette away from the IPL toward the ganglion cell layer. As the puffer pipette was moved, the IPSC amplitude declined with a Gaussian HWHM of $24 \pm 3 \mu \mathrm{m}(n=7$; see Materials and Methods) (supplemental Fig. 1, available at www.jneurosci.org as supplemental material). Because glutamate uptake is likely more capacious within the IPL than in the ganglion cell layer and the bulk superfusion solution flowed in the same direction as the puff, this represents a lower estimate of the spatial resolution achieved with the puffing technique.

\section{$\mathrm{Na}_{\mathrm{v}}$ channels enhance glycinergic feedback onto RBCs}

Feedforward glycinergic inhibition from amacrine cells to ganglion cells depends partially on $\mathrm{Na}_{\mathrm{v}}$ channels (Protti et al., 1997; Cook et al., 1998; Bieda and Copenhagen, 1999). We tested the role of $\mathrm{Na}_{\mathrm{v}}$ channels in glycinergic feedback onto RBCs by applying the $\mathrm{Na}_{\mathrm{v}}$ channel blocker TTX. TTX $(0.5 \mu \mathrm{M})$ reduced feedback IPSCs (puff at $0 \mu \mathrm{m}$ ) significantly but incompletely in rat (Fig. $2 B$ ) and in mouse (WT: $17 \pm 5 \%$ of control, $n=4, p=$ 0.003; Cx36-/-: $10 \pm 3 \%$ of control, $n=7, p=0.0003$ ) (Fig. $2 E)$, consistent with previous reports in rat (Cui et al., 2003). A higher TTX concentration $(2 \mu \mathrm{M})$ exerted similar effects on feedback IPSCs in rat (Fig. $2 \mathrm{~B}$ ), indicating that a minor component of glycinergic feedback occurs independently of $\mathrm{Na}_{\mathrm{v}}$ channels.

\section{RBCs do not receive reciprocal glycinergic feedback}

RBCs receive reciprocal GABAergic feedback inhibition from A17 amacrine cells (Nelson and Kolb, 1985; Sandell and Masland, 1986; Sterling and Lampson, 1986; Hartveit, 1999; Chavez et al., 2006) that is TTX-insensitive (Chavez et al., 2006). Because some interneurons have been shown to corelease GABA and glycine (Jonas et al., 1998), one possibility is that A17s may also release glycine and contribute to the TTX-insensitive component of the glutamate-evoked IPSC. However, IPSCs were unaffected by bath application of DHT ( $50 \mu \mathrm{M}, 10 \mathrm{~min}$; to $96 \pm 5 \%$ of control; $n=5 ; p=0.18$; puff at $0 \mu \mathrm{m})$ (Fig. $2 C, D)$, a neurotoxic serotonin analog that ablates indoleamine accumulating cells such as A17s (Nakatsuka and Hamasaki, 1985; Dong and Hare, 2003; Chavez et al., 2006). Furthermore, the reduction of the IPSC by TTX remained incomplete even in the presence of DHT (Fig. 2C,D). These results indicate that A17s do not release glycine onto RBC terminals and do not contribute to the TTX-insensitive component of the glutamate-evoked IPSC.

RBCs receive "lateral" feedback (synaptic input from amacrine cells activated by other bipolar cells in the retinal circuitry) as well as "reciprocal" feedback (synaptic input from amacrine cells activated directly by the same RBC). Although GABAergic input from A17s is the most thoroughly studied form of reciprocal feedback onto RBCs (Kolb and Nelson, 1983; Raviola and Dacheux, 1987; Hartveit, 1999; Dong and Hare, 2003; Singer and Diamond, 2003; Chavez et al., 2006), anatomical studies of cat retina indicate that $\mathrm{RBCs}$ also receive reciprocal synapses from other amacrine cells as well (Sterling and Lampson, 1986). To test whether RBCs receive glycinergic reciprocal feedback, IPSCs were elicited in RBCs by depolarizing the RBC through the patch electrode (Hartveit, 1999; Chavez et al., 2006) (Fig. 3A). In the absence of GABA receptor (GABAR) antagonists, depolarization elicited a sustained inward $\mathrm{Ca}^{2+}$ current and a transient, outward
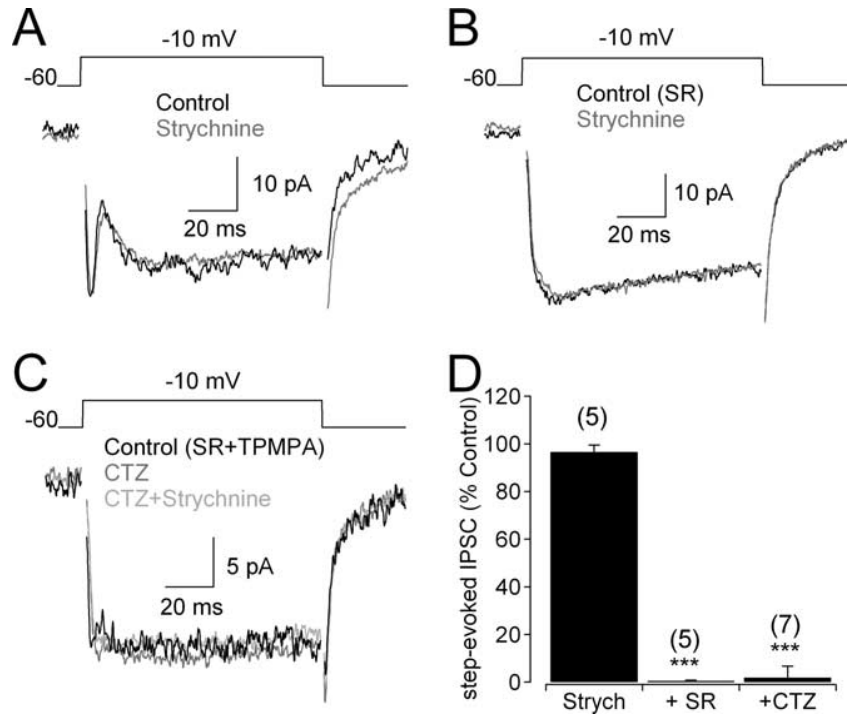

Figure 3. $\mathrm{RBC}$ terminals do not receive reciprocal glycinergic feedback. $\boldsymbol{A}$, In the absence of GABAR antagonists, IPSC s evoked by voltage steps were unaffected by application of strychnine (3 $\mu \mathrm{m}$ ). $\boldsymbol{B}$, When $\mathrm{GABA}_{\mathrm{A}}$ Rs were blocked, no glycinergic step-evoked IPSCs were observed. $\boldsymbol{C}$, Enhancing amacrine cell activation with cyclothiazide $(50 \mu \mathrm{m})$ did not elicit detectable glycinergic step-evoked IPSCs in the presence of $G_{A B A_{A}} R$ and $G_{A B A} R$ antagonists. $D$, Summarized drug effects (mean \pm SD) on step-evoked IPSCS. SR, SR95531; Strych, strychnine; CTZ, cyclothiazide.

IPSC that was unaffected by $3 \mu \mathrm{M}$ strychnine (Fig. $3 A, D$ ) and abolished by the $\mathrm{GABA}_{\mathrm{A}} \mathrm{R}$ antagonist SR95331 (10 $\left.\mu \mathrm{M}\right)$ (Fig. 3D) (see also Singer and Diamond, 2003; Chavez et al., 2006). No reciprocal feedback or strychnine-sensitive current was observed in the presence of GABAR antagonists $(n=6)$ (Fig. $3 B$ ), even when AMPA receptor (AMPAR) activation on amacrine cells was enhanced with cyclothiazide ( $50 \mu \mathrm{M} ; n=5$ ) (Fig. 3C,D) (Singer and Diamond, 2003), indicating that rat RBCs do not receive reciprocal glycinergic feedback. This finding is consistent with evidence suggesting that reciprocal synapses onto RBCs are primarily GABAergic (Chun and Wässle, 1989; Hartveit, 1999).

\section{Multiple glutamate receptors mediate synaptic input to glycinergic amacrine cells}

Amacrine cells express a wide array of ionotropic and metabotropic glutamate receptors, the specific complements of which may vary with cell type and species (Dixon and Copenhagen, 1992; Boos et al., 1993; Hartveit and Veruki, 1997). To identify which glutamate receptors drive the amacrine cells providing glycinergic feedback onto RBCs, we evoked IPSCs with glutamate puffs and tested the effects of different glutamate receptor antagonists. Glutamate-evoked IPSCs were reduced by application of the non-NMDAR antagonist 2,3-dihydroxy-6-nitro-7sulfamoyl-benzo(f)quinoxaline (NBQX; $25 \mu \mathrm{M}$ ) (Fig. 4A,E) or the NMDAR antagonist 3-(2-carboxypiperazine-4-yl) propyl-1phosphonic acid (CPP; $10 \mu \mathrm{M}$ ) (Fig. $4 B, E$ ). Glutamate-evoked IPSCs also were reduced by the AMPAR-specific antagonist GYKI $53655(50 \mu \mathrm{M})$ (Fig. 4C,E) but were only slightly affected by the $\mathrm{Ca}^{2+}$-permeable AMPAR antagonist philanthotoxin 433 (1 $\mu \mathrm{M})$ (Fig. $4 D, E$ ), which completely blocks synaptic inputs to A17 amacrine cells in this preparation (Chavez et al., 2006). Coapplication of CPP and NBQX blocked the feedback IPSC completely (Fig. 4B,E), but CPP and GYKI 53655 did not (Fig. 4C,E), suggesting a small contribution of kainate receptors (KARs) in addition to more prominent contributions of NMDARs and $\mathrm{Ca}^{2+}$ - 
A

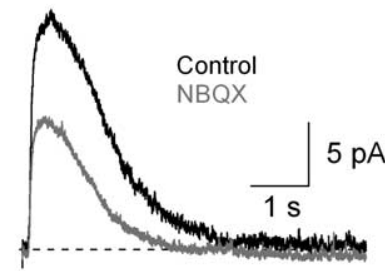

C


Figure 4. Different glutamate receptors mediate activation of glycinergic amacrine cells. $\boldsymbol{A}$, Feedback IPSCs were reduced by the non-NMDAR antagonist NBQX (25 $\mu \mathrm{M})$. $\boldsymbol{B}$, Feedback IPSCS also were reduced by the NMDAR antagonist CPP $(10 \mu \mathrm{M})$ and eliminated by coapplication with NBQX (25 $\mu \mathrm{m})$. C, Feedback IPSCs were reduced by application of the AMPAR antagonist GYKI $53655(50 \mu \mathrm{M})$; coapplication of (PP reduced the IPSC further, but a small component remained. $\boldsymbol{D}$, The $\mathrm{Ca}^{2+}$-permeable AMPARs antagonist philanthotoxin did not reduce IPSCs, but CPP and NBQX eliminated them. $\boldsymbol{E}$, Summarized drug effects (mean \pm SD) on IPSCS. ND, Experiment not done. Experiments were performed in the presence of GABAR antagonists (SR95531 and TPMPA) and DHT. GYKI, GYKI 53655; PhTx, philanthotoxin.

impermeable AMPARs. Similar results were observed in WT mouse RBCs (Fig. 4E).

\section{Glycinergic feedback onto RBCs is driven by the $\mathrm{ON}$ and OFF pathways}

Receptors activated by exogenous ligand are not necessarily activated by synaptically released neurotransmitter. For example, AII amacrine cells in rat retina respond to exogenous NMDA application (Hartveit and Veruki, 1997), but their synaptic inputs from RBCs are mediated entirely by AMPARs (Singer and Diamond, 2003; Veruki et al., 2003). Also, because all bipolar cells are glutamatergic, glutamate puffs in the IPL do not distinguish between glycinergic amacrine cells driven by $\mathrm{ON}$ and OFF bipolar cells. To address these issues, we stimulated ON or OFF bipolar cells independently by puffing either the mGluR antagonist CPPG (Nawy, 2004) or the AMPAR/KAR agonist kainate (DeVries, 2000), respectively, in the OPL. Control experiments with NMDA indicated that agents puffed in the OPL do not diffuse and exert direct actions in the IPL (supplemental Fig. 2, available at www.jneurosci.org as supplemental material) (see also Chavez et al., 2006). Both CPPG and kainate elicited glycin-
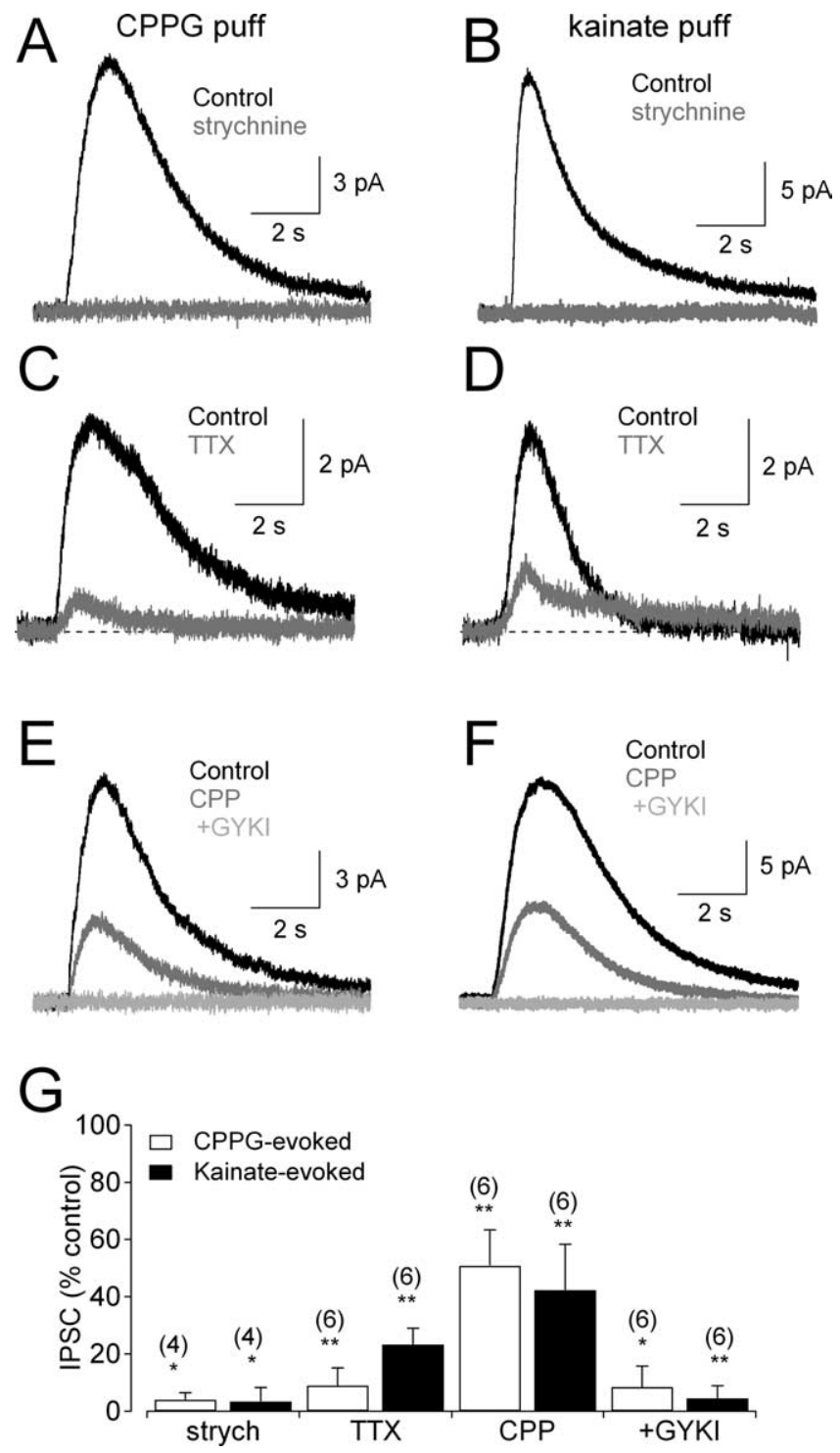

Figure 5. ON and OFF glycinergic amacrine cells provide feedback onto RBC terminals. $\boldsymbol{A}$, Strychnine $(3 \mu \mathrm{M})$-sensitive IPSCs recorded in $\mathrm{RBC}$, elicited by activating $0 \mathrm{~N}$ bipolar cells with puff application of the mGluR antagonist CPPG $(600 \mu \mathrm{m})$ in the OPL. B, Similar results were observed when OFF bipolar cells were activated by puffs of kainate (100 $\mu \mathrm{M})$. C, CPPG-evoked responses were reduced by TTX $(2 \mu \mathrm{M})$. D , Kainate-evoked responses also were reduced by TTX $(2 \mu \mathrm{M})$. E, CPPG-evoked IPSCS were sensitive to coapplication of CPP (10 $\mu \mathrm{M})$ and GYKI 53655 $(50 \mu \mathrm{M}) . \boldsymbol{F}$, Kainate-evoked IPSCs also were sensitive to CPP $(10 \mu \mathrm{M})$ and GYKI $53655(50 \mu \mathrm{M})$. $G$, Summarized drug effects (mean \pm SD) on IPSCs evoked by CPPG (open bars) and kainate (filled bars). All experiments were performed in the presence of GABAR antagonists (SR95531 and TPMPA) and the group III mGluR agonist L-AP-4 (10 $\mu \mathrm{m})$. GYKI, GYKI 53655; strych, strychnine.

ergic IPSCs in RBCs that were abolished by strychnine ( $3 \mu \mathrm{M})$ (Fig. 5A, $B, G$ ), indicating that glycinergic amacrine cells contacting $\mathrm{RBCs}$ receive excitatory inputs from $\mathrm{ON}$ and/or OFF bipolar cells. CPPG- and kainate-evoked responses were blocked strongly by TTX $(0.5 \mu \mathrm{M})$ (Fig. $5 C, D, G)$, which does not affect transmitter release from most bipolar cells (Ichinose et al., 2005; Chavez et al., 2006) but reduces feedback glycinergic transmission from amacrine cells onto RBCs (Fig. 2) (Cui et al., 2003). IPSCs elicited by CPPG (ON) or kainate (OFF) stimulation were reduced to similar extents by CPP $(10 \mu \mathrm{M})$ and abolished by the additional application of GYKI $53655(25 \mu \mathrm{M})$ (Fig. $5 E-G)$. These results indicate that synaptic inputs to these glycinergic amacrine cells are 




B

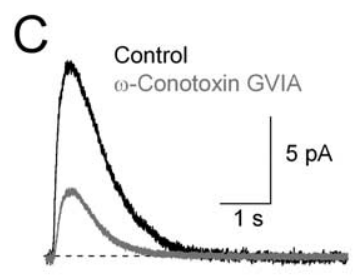



Figure 6. $\mathrm{Ca}^{2+}$ entry through $\mathrm{Ca}_{\mathrm{v}}$ channels and NMDARs triggers glycine release. A, IPSCs were reduced by application of $\mathrm{Cd}^{2+}(200 \mu \mathrm{m})$. The $\mathrm{Cd}^{2+}$-insensitive current was eliminated by application of (PP (10 $\mu \mathrm{M})$. $\boldsymbol{B}$, Summarized drug effects (mean \pm SD) on IPSCs in rat retina. C, IPSC evoked in the presence of CPP (control trace) was reduced by the N-type $\mathrm{Ca}_{\mathrm{v}}$ channel blocker $\omega$-conotoxin GVIA (10 nm). D, Summarized effects of $\mathrm{Ca}_{\mathrm{v}}$ channel blockers (mean \pm SD) on IPSCs in the presence of $10 \mu \mathrm{M}$ CPP (to eliminate $\mathrm{Ca}^{2+}$ influx through NMDARs) and GABAR antagonists (SR95531 and TPMPA). mibef., Mibefradil; israd., isradipine; conotox., conotoxin; Agatox., agatoxin.

mediated by a combination of NMDARs and AMPARs. GYKI 53655 blocked the non-NMDAR component of the IPSC more completely than when IPSCs were evoked by glutamate (Fig. $4 C, E)$, possibly indicating the presence of extrasynaptic KARs that are not strongly activated by glutamate released from bipolar cells.

\section{$\mathrm{Ca}_{\mathrm{v}}$ channels and NMDARs contribute $\mathrm{Ca}^{2+}$ influx to trigger glycine release}

Presynaptic $\mathrm{Ca}_{\mathrm{v}}$ channels typically mediate $\mathrm{Ca}^{2+}$ influx that triggers neurotransmitter release (Katz and Miledi, 1967). Accordingly, glycine release from amacrine cells requires $\mathrm{Ca}_{\mathrm{v}}$ channels (Habermann et al., 2003; Bieda and Copenhagen, 2004). The strong reduction of glutamate-evoked IPSCs by TTX (Fig. $2 B$ ) indicates a role for membrane depolarization and, potentially, $\mathrm{Ca}_{\mathrm{v}}$ channels in glycinergic feedback onto RBCs. Accordingly, $\mathrm{Cd}^{2+}(200 \mu \mathrm{M})$, a broad-spectrum blocker of $\mathrm{Ca}_{\mathrm{v}}$ channels, reduced the IPSC significantly but incompletely (Fig. 6A, B). The $\mathrm{Cd}^{2+}$-insensitive component of the response was abolished by the NMDAR antagonist CPP (10 $\mu \mathrm{M})$ (Fig. 6A,B). Similar results were obtained when the order of drug application was reversed: the CPP-insensitive component of the IPSC ( $58 \pm 6 \%$ of control; $n=6 ; p=0.00006$ ) was blocked completely by $\mathrm{Cd}^{2+}$ (to $1 \pm 1 \%$ of control; $n=6 ; p=0.00001$ ) (see also Chavez et al., 2006). Feedback IPSCs were eliminated completely when $\mathrm{Ca}^{2+}$ was removed from the bath (Fig. $6 \mathrm{~B}$ ), confirming that glycine release is entirely $\mathrm{Ca}^{2+}$ dependent. These results indicate that both $\mathrm{Ca}_{\mathrm{v}}$ channels and NMDARs contribute $\mathrm{Ca}^{2+}$ influx to trigger transmitter release, as shown in the olfactory bulb and goldfish retina (Isaacson and Strowbridge, 1998; Schoppa et al., 1998; Halabisky et al., 2000; Isaacson, 2001; Vigh and von Gersdorff, 2005).

$\mathrm{L}, \mathrm{N}, \mathrm{P} / \mathrm{Q}$, and R-type $\mathrm{Ca}_{\mathrm{v}}$ channels are expressed in the IPL of rat retina (Kamphuis and Hendriksen, 1998; Xu et al., 2002). In mouse retina, AII amacrine cells express only $\mathrm{Ca}_{\mathrm{v}} 1.3$ (L-type) channels (Habermann et al., 2003), and feedforward glycine release from other amacrine cells is triggered by L- and N-type $\mathrm{Ca}_{\mathrm{v}}$ channels (Bieda and Copenhagen, 2004), but it is unknown which $\mathrm{Ca}_{\mathrm{v}}$ channels contribute to glycinergic feedback onto RBCs. To test this, NMDARs were blocked with $10 \mu \mathrm{M} C P P$, and the effects on IPSC amplitude of specific $\mathrm{Ca}_{\mathrm{v}}$ channel antagonists were tested. $\omega$-Conotoxin GVIA (10 nM), an N-type $\mathrm{Ca}_{\mathrm{v}}$ channel antagonist, exerted the largest effect on IPSC amplitude (Fig. $6 C, D)$, followed by the L-type $\mathrm{Ca}_{\mathrm{v}}$ channel antagonist isradipine $(10 \mu \mathrm{M})$ (Fig. 6D). Applied together, $\omega$-conotoxin GVIA and isradipine blocked most of the CPP-resistant IPSC (Fig. 6D), indicating primary roles for $\mathrm{N}$ - and L-type $\mathrm{Ca}_{\mathrm{v}}$ channels. Similar results were observed in mouse ( $\omega$-conotoxin GVIA and isradipine reduced IPSCs to $44 \pm 10 \%$ of control; $n=5 ; p=0.0002)$. Antagonists of T-type (mibefradil, $10 \mu \mathrm{M}), \mathrm{T} / \mathrm{R}$-type $\left(\mathrm{Ni}^{2+}, 100\right.$ $\mu \mathrm{M}$ ), and P/Q-type (agatoxin IVA, $200 \mathrm{nM}$ ) $\mathrm{Ca}_{\mathrm{v}}$ channels exerted relatively minor, albeit statistically significant, effects on IPSC amplitude (Fig. 6D). T, R, and P/Q channels each may constitute a very small fraction of the $\mathrm{Ca}_{\mathrm{v}}$ population in amacrine cells, and their contribution may be magnified by cooperativity between $\mathrm{Ca}^{2+}$ influx and transmitter release (Xu and $\left.\mathrm{Wu}, 2005\right)$. For example, with fourth-power cooperativity, blocking just $5 \%$ of the $\mathrm{Ca}_{\mathrm{v}}$ channels would reduce release by $19 \%$, similar to the reduction observed with several $\mathrm{Ca}_{\mathrm{v}}$ antagonists (Fig. $6 \mathrm{D}$ ).

\section{CICR enhances NMDAR and $\mathrm{Ca}_{\mathrm{v}}$ channel-mediated $\mathrm{Ca}^{2+}$ signaling through different pathways}

CICR from intracellular endoplasmic reticulum (ER) stores contributes to intracellular $\mathrm{Ca}^{2+}$ signaling and neurotransmitter release in some GABAergic amacrine cells (Vigh and Lasater, 2003; Warrier et al., 2005; Chavez et al., 2006), but roles for CICR in glycinergic amacrine cells have not been explored. Depletion of $\mathrm{ER} \mathrm{Ca}^{2+}$ stores with thapsigargin $(1 \mu \mathrm{M})$ reduced feedback IPSCs in both rat and mouse (Fig. $7 A, B$ ), suggesting a role for CICR in glycinergic feedback. CICR in GABAergic amacrine cells has been shown to be mediated by ryanodine receptors (RyRs) and/or inositol-1,4,5-trisphosphate receptors ( $\mathrm{IP}_{3} \mathrm{Rs}$ ), ligand-gated calcium channels in the ER membrane (Vigh and Lasater, 2003; Warrier et al., 2005; Chavez et al., 2006). Pharmacological experiments indicated a role for both receptor types in glycinergic feedback: the RyR antagonist ruthenium red (RR; $40 \mu \mathrm{M})$ reduced IPSCs (Fig. $7 B$ ), as did two different $\mathrm{IP}_{3} \mathrm{R}$ antagonists, 2-APB $(50 \mu \mathrm{M})$ (Fig. $7 B)$ and xestospongin $\mathrm{C}(3 \mu \mathrm{M})$ (Fig. $7 B$ ). Similar effects of RR and 2-APB were observed in mouse (Fig. $7 B)$. As a further indication that RyRs contribute to glycine release, puff application of the RyR agonist caffeine $(15 \mathrm{~mm})$ in rat evoked glycinergic IPSCs that were blocked by strychnine (to $5 \pm$ $3 \%$ of control; $n=4 ; p=0.01$ ) and reduced by RR (to $9 \pm 2 \%$ of control; $n=5 ; p=0.0005$; data not shown).

Experiments described in Figure 6 indicate that $\mathrm{Ca}^{2+}$ influx through both NMDARs and $\mathrm{Ca}_{\mathrm{v}}$ channels can trigger glycine release. To test whether these different sources of $\mathrm{Ca}^{2+}$ influx use distinct CICR mechanisms, RR and 2-APB were applied separately to rat slices in the presence of NMDAR or $\mathrm{Ca}_{\mathrm{v}}$ channel antagonists. RR exerted no significant effect when applied in the presence of the $\mathrm{Ca}_{\mathrm{v}}$ channel blocker $\mathrm{Cd}^{2+}(200 \mu \mathrm{M} ; 95 \pm 6 \%$ of $\mathrm{Cd}^{2+}$ alone; $n=6 ; p=0.09$ ) (Fig. 7C,G), whereas 2-APB reduced IPSCs significantly (to $72 \pm 15 \%$ of $\mathrm{Cd}^{2+}$ alone; $n=6 ; p=0.005$ ) (Fig. $7 E, G$ ). Conversely, in the presence of the NMDAR antagonist CPP $(10 \mu \mathrm{M})$, RR reduced IPSCs significantly (to $70 \pm 15 \%$ of CPP alone; $n=6 ; p=0.002$ ) (Fig. $7 D, H$ ), but 2-APB did not (93 $\pm 7 \%$ of CPP alone; $n=6 ; p=0.08)$ (Fig. $7 F, H)$. The lack of 2 -APB effect in the presence of CPP argues against any nonspecific actions of 2-APB on gap junctions (Harks et al., 2003) or transient receptor potential channels (Chung et al., 2004) in these experiments. These results indicate that NMDAR- and $\mathrm{Ca}_{\mathrm{v}}$ 
A


C
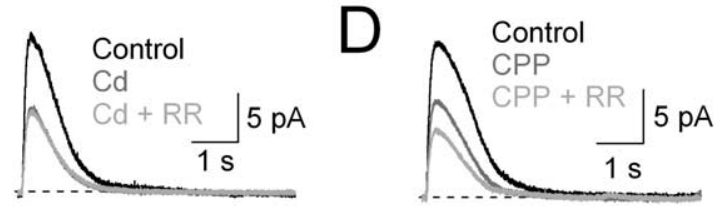
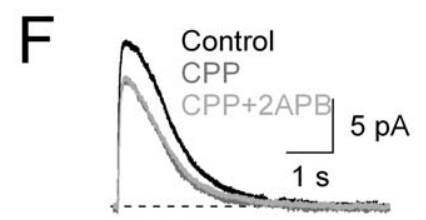
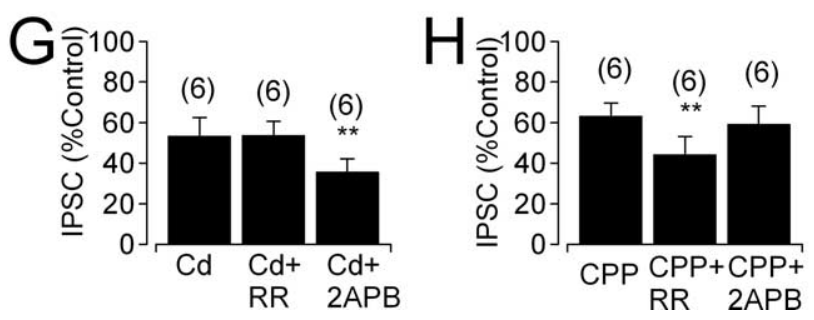

Figure 7. $\quad I_{3} R$ s and RyRs contribute to $C I C R$ in glycinergic amacrine cells. $A$, Feedback IPSC before and after bath application of thapsigargin $(1 \mu \mathrm{M})$. $\boldsymbol{B}$, Summarized effects (mean \pm SD) of thapsigargin (1 $\mu \mathrm{m}), \operatorname{RR}(40 \mu \mathrm{m}), 2-\mathrm{APB}(50 \mu \mathrm{m})$, and xestospongin $\mathrm{C}(\mathrm{XeC} ; 3 \mu \mathrm{m})$ on IPSCs. ND, Experiment not done. C, IPSCs recorded under control conditions, in the presence of $\mathrm{Cd}^{2+}$ and the additional presence of RR. D, IPSCs recorded under control conditions, in the presence of CPP and the additional presence of the RR. $\boldsymbol{E}, \boldsymbol{F}$, As in $\boldsymbol{C}$ and $\boldsymbol{D}$, but with the $I \mathrm{P}_{3} R$ antagonist 2-APB. G, $\boldsymbol{H}$, Summarized data (mean \pm SD) showing that $I_{3}$ Rs and RyRs amplify specifically NMDAR-mediated and $\mathrm{Ca}_{v}$ channel-mediated $\mathrm{Ca}^{2+}$ signals, respectively. All experiments were performed in the presence of GABAR antagonists (SR95531 and TPMPA).

channel-mediated $\mathrm{Ca}^{2+}$ influx is functionally segregated and specifically coupled to $\mathrm{IP}_{3}$ Rs and RyRs, respectively.

\section{mGluR1 contributes to $\mathrm{IP}_{3}$ signaling in glycinergic} amacrine cells

Whereas RyRs are activated solely by increases in intracellular $\mathrm{Ca}^{2+}, \mathrm{IP}_{3} \mathrm{Rs}$ require coactivation by $\mathrm{Ca}^{2+}$ and $\mathrm{IP}_{3}$ (Finch et al., 1991; Berridge, 1998). $\mathrm{IP}_{3}$ is produced by phospholipase $\mathrm{C}$, which is activated via $\mathrm{G}_{\mathrm{q}}$-protein-coupled receptors such as group I mGluRs (Bezprozvanny et al., 1991; Finch et al., 1991; Verkhratsky and Petersen, 2002). To examine the role of mGluRs in amacrine cell $\mathrm{IP}_{3}$ signaling, IPSCs were recorded in the presence of $\mathrm{Cd}^{2+}$ to isolate the NMDAR-mediated, $\mathrm{IP}_{3} \mathrm{R}$-dependent component. Under these conditions, IPSCs were reduced by the group I mGluR antagonist $(S)-(+)$ - $\alpha$-amino-4-carboxy-2methylbenzeneacetic acid (LY367385; $50 \mu \mathrm{M}$ ) (Fig. 8A,E). Although group I includes mGluR1 and mGluR5, LY367385 at this concentration is specific for mGluR1 (Clark et al., 1997); the specific mGluR5 antagonist 2-methyl-6-(phenylethynyl)pyridine (MPEP; $30 \mu \mathrm{M}$ ) did not reduce IPSC amplitude (Fig. $8 B, E)$. Neither the group II mGluR antagonist LY341495 (5 $\mu \mathrm{M})$



B mGluR5 (PLC)
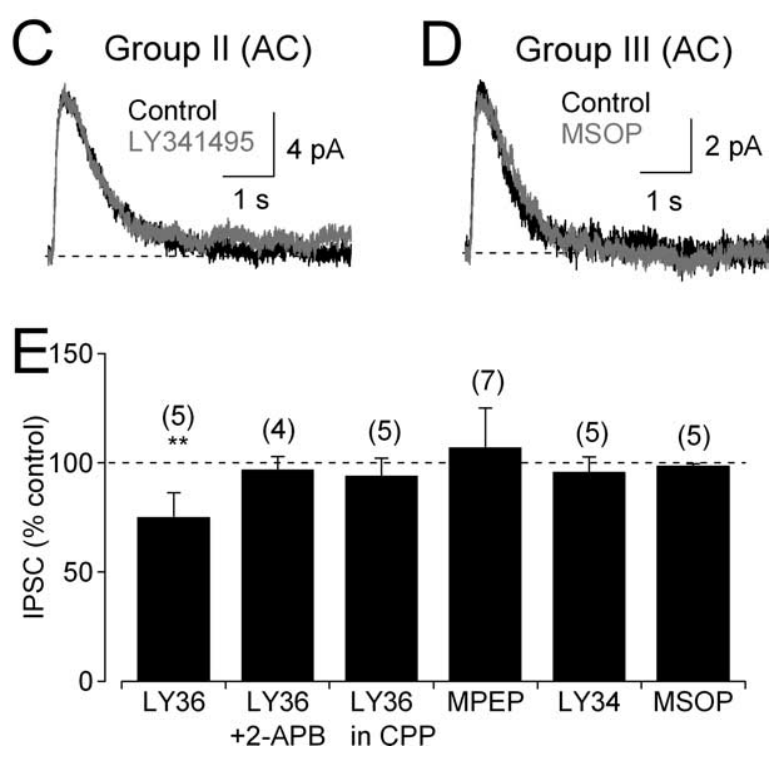

Figure 8. mGluR1s contribute to $\mathbb{P}_{3}$ signaling in glycinergic amacrine cells. $\boldsymbol{A}$, In the presence of $\mathrm{Cd}^{2+}$ to abolish $\mathrm{Ca}^{2+}$ influx through $\mathrm{Ca}_{v}$ channels, the mGluR1 antagonist LY367385 $(50 \mu \mathrm{m})$ reduced IPSCS. $\boldsymbol{B}$, The mGluR5 antagonist MPEP $(30 \mu \mathrm{m})$ did not reduce IPSCS. $\boldsymbol{C}$, The group II mGluR antagonist LY341495 (5 $\mu \mathrm{m}$ ) did not reduce IPSCS. D, The group III mGluR antagonist MSOP (100 $\mu \mathrm{m})$ did not reduce IPSCS. $\boldsymbol{E}$, Summarized effects of mGluR antagonists (mean \pm SD). PLC, Phospholipase C; AC, adenylyl cyclase; LY36, LY367385; LY34, LY341495.

(Fig. 8C,E) nor the group III antagonist MSOP $(100 \mu \mathrm{M})$ (Fig. $8 D, E)$ reduced IPSCs significantly. mGluR1 does not contribute to glycine release in the absence of $\mathrm{IP}_{3}$-mediated signaling, because LY367385 had no effect on IPSCs in the presence of the $\mathrm{IP}_{3} \mathrm{R}$ antagonist 2-APB or in the presence of CPP instead of $\mathrm{Cd}^{2+}$ (Fig. $8 E$ ).

To test whether mGluR1 modulation of glycinergic feedback can be triggered by synaptically released glutamate, effects of LY367385 were tested on IPSCs elicited by stimulation of ON or OFF bipolar cells with CPPG or kainate. LY367385 (50 $\mu \mathrm{M})$ exerted insignificant effects on IPSCs evoked by puffs of CPPG (97 $\pm 5 \%$ of control; $n=4 ; p=0.31$ ) (supplemental Fig. $3 A, D$, available at www.jneurosci.org as supplemental material) or kainate ( $92 \pm 9 \%$ of control; $n=4 ; p=0.18$ ) (supplemental Fig. $3 B, D$, available at www.jneurosci.org as supplemental material). In addition, LY367385 did not affect CPPG-evoked EPSCs in AII amacrine cells ( $97 \pm 3 \%$ of control; $n=4 ; p=0.14$ ) (supplemental Fig. 3C, D, available at www.jneurosci.org as supplemental material), indicating that it did not alter glutamate release from RBCs. These negative results may reflect the relatively small impact of LY367385 on glycine release, even when $\mathrm{Ca}_{\mathrm{v}}$ channels were blocked by $\mathrm{Cd}^{2+}$ (25\% reduction) (Fig. 8A,E). With $\mathrm{Ca}_{\mathrm{v}}$ channels functional (a requirement for $\mathrm{CPPG} / \mathrm{kainate}$-evoked responses), the NMDAR-mediated ( $\mathrm{IP}_{3} \mathrm{R}$-dependent) pathway triggers only about one-half of the glycine release (Fig. $6 B$ ), so the effect of LY367385 is predicted to be even smaller, and possibly diminished still further if mGluR1s are extrasynaptic and acti- 
vated more strongly by exogenous glutamate than by synaptically released transmitter.

\section{Discussion}

The experiments presented here investigate the cellular and synaptic mechanisms underlying glycinergic inhibitory feedback onto rat and mouse RBC axons and synaptic terminals. Feedback and feedforward glycinergic inhibition are prominent features of the inner retinal circuitry, regulating glutamate release from bipolar cells and synaptic integration in amacrine and ganglion cells, so it is important to understand how glycinergic amacrine cells integrate synaptic excitation to trigger release of inhibitory neurotransmitter. This is a particularly interesting question in these relatively small neurons in which synaptic inputs and outputs occur within the same compact dendritic arbor (MacNeil and Masland, 1998). By studying glycinergic feedback onto $\mathrm{RBCs}$, we not only examine a process that shapes signaling in the rod pathway (Eggers and Lukasiewicz, 2006a), we also focus on a functional subset of amacrine cells in an effort to understand general principles governing the physiology of this complex neuron class. The mammalian retina contains about two dozen different amacrine cell types, at about one-half of which are glycinergic (MacNeil and Masland, 1998; Menger et al., 1998). Individual cells apparently can mediate both feedforward and feedback inhibition [e.g., AIIs (Murphy and Rieke, 2008)], but the rich diversity and precise morphological and functional specification of individual cell types suggest that such circuitry features often may be contributed by different cell types (MacNeil and Masland, 1998; Menger et al., 1998). Although AII amacrine cells provide a significant fraction of the glycinergic feedback to OFF cone bipolars (Kolb and Nelson, 1983; Dacheux and Raviola, 1986; Strettoi et al., 1990), AIIs constitute only 25\% of the glycinergic amacrine cells (MacNeil and Masland, 1998; Menger et al., 1998); the diversity of bipolar cell targets [RBCs and many different cone bipolar cell types exhibit glycine sensitivity (Ivanova et al., 2006)] suggests further functional segregation. It may be, then, that only a small number of individual cell types provide glycinergic feedback to RBCs. Distinguishing diversity of amacrine cell types from diversity of function within individual cells will require recordings from single neurons identified by specific molecular markers that have yet to be developed.

\section{No reciprocal glycinergic feedback onto $\mathrm{RBC}$ synaptic terminals}

Step depolarization of the RBC membrane elicits GABAergic IPSCs via immediately reciprocal feedback (Hartveit, 1999; Singer and Diamond, 2003; Chavez et al., 2006) accomplished by adjacent postsynaptic glutamate receptors and GABA release machinery in A17 amacrine cells (Nelson and Kolb, 1985; Sandell and Masland, 1986; Sterling and Lampson, 1986; Chavez et al., 2006). In contrast, no reciprocal glycinergic feedback was observed in RBCs (Fig. 3), indicating that the conversion from excitatory synaptic input to feedback glycine release involves some spread of the excitatory signal through, and integration within, amacrine cell dendritic arbors. Here, we consider this excitatory signal to comprise two primary components, a membrane depolarization and an increase in intracellular $\mathrm{Ca}^{2+}$. Although either component could be distributed between cells via gap junctions, shown here to contribute to the spatial extent of glycinergic inhibition (Fig. 2E), each are generated and amplified by distinct cellular processes. We discuss below the cellular mechanisms underlying each component of the excitatory signal and specific functional links between them.

\section{Electrical integration in glycinergic amacrine cells}

Synaptically activated membrane depolarization could spread passively through the dendrites to activate $\mathrm{Ca}_{\mathrm{v}}$ channels and trigger glycine release, particularly if compact morphology rendered the dendritic arbor essentially isopotential (MacNeil and Masland, 1998). Consistent with previous work (Protti et al., 1997; Cook et al., 1998; Bieda and Copenhagen, 1999; Cui et al., 2003), however, we found that glycinergic transmission depends strongly, although incompletely, on $\mathrm{Na}_{\mathrm{v}}$ channels (Figs. 2, 5). Besides boosting dendritic depolarization to enhance transmitter release, $\mathrm{Na}_{\mathrm{v}}$ channels also could enhance the spread of membrane depolarization in a nonisopotential dendritic arbor and, through gap junctions, into the dendritic arbors of electrically coupled cells (Fig. 2E).

The spatial extent of glycinergic feedback onto RBCs is enhanced by Cx36 gap junctions (Fig. 2), which are preferentially expressed in AII amacrine cells and cone bipolar cells (Mills et al., 2001; Deans et al., 2002). AIIs probably do not provide glycinergic feedback onto RBCs: (1) morphological evidence indicates that AIIs do not make reciprocal feedback synapses onto RBCs (Kolb and Nelson, 1983; Dacheux and Raviola, 1986; Sterling and Lampson, 1986); (2) synaptic activation of AIIs via RBC depolarization (Singer and Diamond, 2003; Singer et al., 2004) does not elicit glycinergic feedback in RBCs (Fig. 3); (3) although NMDARs mediate synaptic activation of amacrine cells providing glycinergic feedback (Fig. 5), AIIs receive their synaptic input only through AMPARs (Singer and Diamond, 2003); (4) glycinergic feedback is triggered in part by $\mathrm{N}$-type $\mathrm{Ca}_{\mathrm{v}}$ channels (Fig. 6), but AIIs express only L-type channels (Habermann et al., 2003); and (5) a portion of glycinergic feedback is driven through the OFF pathway (Fig. 5), but AIIs are activated primarily by (ON) RBCs. AIIs, stimulated by glutamate or synaptic input from RBCs, could contribute indirectly to glycinergic feedback via Cx36 gap junctions to ON cone bipolar cells (Mills et al., 2001) that, in turn, excite other ON glycinergic amacrine cells that contact RBCs. This circuit, although possible, apparently is not prevalent, because depolarization of a single RBC does not elicit glycinergic feedback in the same cell (Fig. 3). It seems more likely that lower levels of $\mathrm{Cx} 36$ could underlie coupling between other types of glycinergic amacrine cells.

\section{$\mathrm{Ca}^{2+}$ signal integration in glycinergic amacrine cells}

Typically, most presynaptic $\mathrm{Ca}^{2+}$ influx is mediated by $\mathrm{Ca}_{\mathrm{v}}$ channels (Katz and Miledi, 1967), although GABA release from olfactory bulb granule cells may be triggered by $\mathrm{Ca}^{2+}$ influx through both $\mathrm{Ca}_{\mathrm{v}}$ channels and NMDARs (Isaacson and Strowbridge, 1998; Schoppa et al., 1998; Halabisky et al., 2000). NMDARs also contribute to feedback release at reciprocal GABAergic synapses onto RBCs in goldfish retina (Vigh and von Gersdorff, 2005), but not in rat retina, where synaptic $\mathrm{Ca}^{2+}$ influx to A17 amacrine cells is mediated by $\mathrm{Ca}^{2+}$-permeable AMPARs (Chavez et al., 2006). Here, we find that transmitter release from glycinergic amacrine cells is triggered by $\mathrm{Ca}^{2+}$ influx through both NMDARs and $\mathrm{Ca}_{\mathrm{v}}$ channels, predominantly the $\mathrm{L}$ and $\mathrm{N}$ subtypes (Fig. 6) (Bieda and Copenhagen, 2004). L-type channels typically trigger transmitter release at continually releasing synapses (Sterling and Matthews, 2005), whereas N-type channels mediate release at many synapses triggered by phasic depolarization (Reid et al., 2003). This combination of $\mathrm{Ca}_{\mathrm{v}}$ channels may reflect the hybrid physiology of glycinergic amacrine cells, which respond to slow light-evoked synaptic input with relatively prolonged depolarization (Nelson, 1982) yet often are capable of generating action potentials (Bloomfield, 1992; Heflin and Cook, 2007). This 
generalization may not apply to AII amacrine cells, spiking neurons that express only L-type $\left(\mathrm{Ca}_{\mathrm{v}} 1.3\right)$ channels (Habermann et al., 2003).

Previous work has shown that CICR enhances neurotransmitter release from GABAergic amacrine cells (Warrier et al., 2005; Chavez et al., 2006). CICR is observed in many neuronal types and usually is mediated by $\mathrm{IP}_{3} \mathrm{Rs}$ and/or RyRs (Berridge, 1998). Interestingly, the two reports of CICR contributing to GABA release from amacrine cells implicate different pathways: in rat A17 cells, release is triggered via RyR activation (Chavez et al., 2006); in amacrine cells cultured from chick retina, although functional RyRs also are present, only $\mathrm{IP}_{3} \mathrm{R}$ activation triggers GABA release (Warrier et al., 2005). Here, we find that both RyRs and $\mathrm{IP}_{3} \mathrm{Rs}$ contribute to feedback glycine release onto RBCs and that the contribution of either pathway depends on the source of $\mathrm{Ca}^{2+}$ influx: RyRs boost the $\mathrm{Ca}^{2+}$ signal mediated by $\mathrm{Ca}_{\mathrm{v}}$ channels, and $\mathrm{IP}_{3} \mathrm{Rs}$ boost the $\mathrm{Ca}^{2+}$ signal entering the cell through NMDARs (Fig. 7). RyR- and $\mathrm{IP}_{3} \mathrm{R}$-mediated signaling often occur in the same neurons (Berridge, 1998); it remains to be determined whether the apparent specificity of the $\mathrm{Ca}_{\mathrm{v}}-\mathrm{RyR}$ and NMDAR- $\mathrm{IP}_{3} \mathrm{R}$ pathways indicates independent $\mathrm{Ca}^{2+}$ signaling within individual cells or functional segregation between different amacrine cell types.

\section{RBCs receive glycinergic feedback inhibition from the $\mathrm{ON}$ and OFF pathways}

GABAergic amacrine cells generally extend their dendritic arbors laterally but restrict their vertical spread to narrow strata within the IPL, usually keeping within the ON or OFF sublamina (MacNeil and Masland, 1998). Glycinergic amacrine cells, in contrast, usually extend dendrites only a short lateral distance but span a significant vertical fraction of the IPL, often occupying both the ON and OFF layers (MacNeil and Masland, 1998; Menger et al., 1998). Accordingly, here we find that glycinergic input to RBCs is driven through both the $\mathrm{ON}$ and OFF pathways (Fig. 5). The inhibitory input from RBCs to the OFF pathway via AIIs has been well described (Kolb and Nelson, 1983; Dacheux and Raviola, 1986; Strettoi et al., 1990). Our results indicate that a converse route also exists, enabling the OFF pathway to inhibit RBCs. Although glycinergic feedback to RBCs may be supplied by purely $\mathrm{ON}$ and OFF amacrine cells, the broad stratification of glycinergic amacrine cell dendrites with the IPL suggests that individual cells may receive input from both channels. Consistent with this latter possibility, some amacrine cells in the salamander retina respond to both the onset and offset of light stimulation (Dixon and Copenhagen, 1992). Interestingly, these cells are driven synaptically by both AMPARs and NMDARs (Dixon and Copenhagen, 1992), analogous to our results in rat (Figs. 4, 5).

ON-driven feedback inhibition of ON RBCs reflects typical feedback control circuitry, but the physiological consequences of OFF inhibition of RBCs is less clear. During darkness, when glutamate release from OFF bipolar cells is relatively high, the OFF feedback signal may enhance the signal-to-noise characteristics of the rod pathway by hyperpolarizing RBC terminals and reducing "background" neurotransmitter release from RBCs.

\section{References}

Berridge MJ (1998) Neuronal calcium signaling. Neuron 21:13-26.

Bezprozvanny I, Watras J, Ehrlich BE (1991) Bell-shaped calcium-response curves of Ins $(1,4,5) \mathrm{P} 3$ - and calcium-gated channels from endoplasmic reticulum of cerebellum. Nature 351:751-754.

Bieda MC, Copenhagen DR (1999) Sodium action potentials are not required for light-evoked release of GABA or glycine from retinal amacrine cells. J Neurophysiol 81:3092-3095.
Bieda MC, Copenhagen DR (2004) N-type and L-type calcium channels mediate glycinergic synaptic inputs to retinal ganglion cells of tiger salamanders. Vis Neurosci 21:545-550.

Boos R, Schneider H, Wässle H (1993) Voltage- and transmitter-gated currents of all-amacrine cells in a slice preparation of the rat retina. J Neurosci 13:2874-2888.

Chavez AE, Singer JH, Diamond JS (2006) Fast neurotransmitter release triggered by Ca influx through AMPA-type glutamate receptors. Nature 443:705-708.

Chun MH, Wässle H (1989) GABA-like immunoreactivity in the cat retina: electron microscopy. J Comp Neurol 279:55-67.

Chung MK, Lee H, Mizuno A, Suzuki M, Caterina MJ (2004) 2-Aminoethoxydiphenyl borate activates and sensitizes the heat-gated ion channel TRPV3. J Neurosci 24:5177-5182.

Clark BP, Baker SR, Goldsworthy J, Harris JR, Kingston AE (1997) (+)-2Methyl-4-carboxyphenylglycine (LY367385) selectively antagonizes metabotropic mGluR1 receptors. Bioorg Med Chem Lett 7:2777-2780.

Cook PB, Lukasiewicz PD, McReynolds JS (1998) Action potentials are required for the lateral transmission of glycinergic transient inhibition in the amphibian retina. J Neurosci 18:2301-2308.

Cui J, Ma YP, Lipton SA, Pan ZH (2003) Glycine receptors and glycinergic synaptic input at the axon terminals of mammalian retinal rod bipolar cells. J Physiol 553:895-909.

Dacheux RF, Raviola E (1986) The rod pathway in the rabbit retina: a depolarizing bipolar and amacrine cell. J Neurosci 6:331-345.

Deans MR, Volgyi B, Goodenough DA, Bloomfield SA, Paul DL (2002) Connexin 36 is essential for transmission of rod-mediated visual signals in the mammalian retina. Neuron 36:703-712.

DeVries SH (2000) Bipolar cells use kainate and AMPA receptors to filter visual information into separate channels. Neuron 28:847-856.

Dixon DB, Copenhagen DR (1992) Two types of glutamate receptors differentially excite amacrine cells in the tiger salamander retina. J Physiol 449:589-606.

Dong CJ, Hare WA (2003) Temporal modulation of scotopic visual signals by A17 amacrine cells in mammalian retina in vivo. J Neurophysiol $89: 2159-2166$

Eggers ED, Lukasiewicz PD (2006a) GABA(A), GABA(C) and glycine receptor-mediated inhibition differentially affects light-evoked signalling from mouse retinal rod bipolar cells. J Physiol 572:215-225.

Eggers ED, Lukasiewicz PD (2006b) Receptor and transmitter release properties set the time course of retinal inhibition. J Neurosci 26:9413-9425.

Euler T, Wässle H (1995) Immunocytochemical identification of cone bipolar cells in the rat retina. J Comp Neurol 361:461-478.

Finch EA, Turner TJ, Goldin SM (1991) Calcium as a coagonist of inositol 1,4,5-trisphosphate-induced calcium release. Science 252:443-446.

Gillette MA, Dacheux RF (1995) GABA- and glycine-activated currents in the rod bipolar cell of the rabbit retina. J Neurophysiol 74:856-875.

Guldenagel M, Ammermuller J, Feigenspan A, Teubner B, Degen J, Sohl G, Willecke K, Weiler R (2001) Visual transmission deficits in mice with targeted disruption of the gap junction gene connexin36. J Neurosci 21:6036-6044.

Habermann CJ, O’Brien BJ, Wässle H, Protti DA (2003) AII amacrine cells express L-type calcium channels at their output synapses. J Neurosci 23:6904-6913.

Halabisky B, Friedman D, Radojicic M, Strowbridge BW (2000) Calcium influx through NMDA receptors directly evokes GABA release in olfactory bulb granule cells. J Neurosci 20:5124-5134.

Harks EG, Camina JP, Peters PH, Ypey DL, Scheenen WJ, van Zoelen EJ, Theuvenet AP (2003) Besides affecting intracellular calcium signaling, 2-APB reversibly blocks gap junctional coupling in confluent monolayers, thereby allowing measurement of single-cell membrane currents in undissociated cells. FASEB J 17:941-943.

Hartveit E (1999) Reciprocal synaptic interactions between rod bipolar cells and amacrine cells in the rat retina. J Neurophysiol 81:2923-2936.

Hartveit E, Veruki ML (1997) AII amacrine cells express functional NMDA receptors. Neuroreport 8:1219-1223.

Heflin SJ, Cook PB (2007) Narrow and wide field amacrine cells fire action potentials in response to depolarization and light stimulation. Vis Neurosci 24:197-206.

Ichinose T, Shields CR, Lukasiewicz PD (2005) Sodium channels in transient retinal bipolar cells enhance visual responses in ganglion cells. J Neurosci 25:1856-1865. 
Isaacson JS (2001) Mechanisms governing dendritic gamma-aminobutyric acid (GABA) release in the rat olfactory bulb. Proc Natl Acad Sci U S A 98:337-342.

Isaacson JS, Strowbridge BW (1998) Olfactory reciprocal synapses: dendritic signaling in the CNS. Neuron 20:749-761.

Ivanova E, Muller U, Wässle H (2006) Characterization of the glycinergic input to bipolar cells of the mouse retina. Eur J Neurosci 23:350-364.

Jonas P, Bischofberger J, Sandkuhler J (1998) Corelease of two fast neurotransmitters at a central synapse. Science 281:419-424.

Kamphuis W, Hendriksen H (1998) Expression patterns of voltagedependent calcium channel alpha 1 subunits (alpha 1A-alpha 1E) mRNA in rat retina. Brain Res Mol Brain Res 55:209-220.

Katz B, Miledi R (1967) Ionic requirements of synaptic transmitter release. Nature 215:651.

Kolb H, Nelson R (1981) Amacrine cells of the cat retina. Vision Res 21:1625-1633.

Kolb H, Nelson R (1983) Rod pathways in the retina of the cat. Vision Res 23:301-312.

Kolb H, Nelson R (1996) Hyperpolarizing, small-field, amacrine cells in cone pathways of cat retina. J Comp Neurol 371:415-436.

Kolb H, Nelson R, Mariani A (1981) Amacrine cells, bipolar cells and ganglion cells of the cat retina: a Golgi study. Vision Res 21:1081-1114.

MacNeil MA, Masland RH (1998) Extreme diversity among amacrine cells: implications for function. Neuron 20:971-982.

Menger N, Pow DV, Wässle H (1998) Glycinergic amacrine cells of the rat retina. J Comp Neurol 401:34-46.

Mills SL, O’Brien JJ, Li W, O’Brien J, Massey SC (2001) Rod pathways in the mammalian retina use connexin 36. J Comp Neurol 436:336-350.

Murphy G, Rieke F (2008) Signals and noise in an inhibitory interneuron diverge to control activity in nearby retinal ganglion cells. Nat Neurosci $11: 318-326$.

Nakatsuka K, Hamasaki DI (1985) Destruction of the indoleamineaccumulating amacrine cells alters the ERG of rabbits. Invest Ophthalmol Vis Sci 26:1109-1116.

Nawy S (2004) Desensitization of the mGluR6 transduction current in tiger salamander On bipolar cells. J Physiol 558:137-146.

Nelson R (1982) AII amacrine cells quicken time course of rod signals in the cat retina. J Neurophysiol 47:928-947.

Nelson R, Kolb H (1985) A17: a broad-field amacrine cell in the rod system of the cat retina. J Neurophysiol 54:592-614.

Pourcho RG, Goebel DJ (1985) Immunocytochemical demonstration of glycine in retina. Brain Res 348:339-342.

Pourcho RG, Goebel DJ (1987) Visualization of endogenous glycine in cat retina: an immunocytochemical study with Fab fragments. J Neurosci 7:1189-1197.

Protti DA, Llano I (1998) Calcium currents and calcium signaling in rod bipolar cells of rat retinal slices. J Neurosci 18:3715-3724.
Protti DA, Gerschenfeld HM, Llano I (1997) GABAergic and glycinergic IPSCs in ganglion cells of rat retinal slices. J Neurosci 17:6075-6085.

Raviola E, Dacheux RF (1987) Excitatory dyad synapse in rabbit retina. Proc Natl Acad Sci U S A 84:7324-7328.

Reid CA, Bekkers JM, Clements JD (2003) Presynaptic Ca2+ channels: a functional patchwork. Trends Neurosci 26:683-687.

Sandell JH, Masland RH (1986) A system of indoleamine-accumulating neurons in the rabbit retina. J Neurosci 6:3331-3347.

Schoppa NE, Kinzie JM, Sahara Y, Segerson TP, Westbrook GL (1998) Dendrodendritic inhibition in the olfactory bulb is driven by NMDA receptors. J Neurosci 18:6790-6802.

Singer JH, Diamond JS (2003) Sustained $\mathrm{Ca}^{2+}$ entry elicits transient postsynaptic currents at a retinal ribbon synapse. J Neurosci 23:10923-10933.

Singer JH, Lassova L, Vardi N, Diamond JS (2004) Coordinated multivesicular release at a mammalian ribbon synapse. Nat Neurosci 7:826-833.

Sterling P, Lampson LA (1986) Molecular specificity of defined types of amacrine synapse in cat retina. J Neurosci 6:1314-1324.

Sterling P, Matthews G (2005) Structure and function of ribbon synapses. Trends Neurosci 28:20-29.

Strettoi E, Dacheux RF, Raviola E (1990) Synaptic connections of rod bipolar cells in the inner plexiform layer of the rabbit retina. J Comp Neurol 295:449-466.

Suzuki S, Tachibana M, Kaneko A (1990) Effects of glycine and GABA on isolated bipolar cells of the mouse retina. J Physiol (Lond) 421:645-662.

Vaney DI (1994) Patterns of neuronal coupling in the retina. Prog Retin Eye Res 13:301-355.

Verkhratsky A, Petersen $\mathrm{OH}$ (2002) The endoplasmic reticulum as an integrating signalling organelle: from neuronal signalling to neuronal death. Eur J Pharmacol 447:141-154.

Veruki ML, Morkve SH, Hartveit E (2003) Functional properties of spontaneous EPSCs and non-NMDA receptors in rod amacrine (AII) cells in the rat retina. J Physiol 549:759-774.

Vigh J, Lasater EM (2003) Intracellular calcium release resulting from mGluR1 receptor activation modulates GABAA currents in wide-field retinal amacrine cells: a study with caffeine. Eur J Neurosci 17:2237-2248.

Vigh J, von Gersdorff H (2005) Prolonged reciprocal signaling via NMDA and GABA receptors at a retinal ribbon synapse. J Neurosci 25:11412-11423.

Warrier A, Borges S, Dalcino D, Walters C, Wilson M (2005) Calcium from internal stores triggers GABA release from retinal amacrine cells. J Neurophysiol 94:4196-4208.

Xu HP, Zhao JW, Yang XL (2002) Expression of voltage-dependent calcium channel subunits in the rat retina. Neurosci Lett 329:297-300.

$\mathrm{Xu} \mathrm{J,} \mathrm{Wu} \mathrm{LG} \mathrm{(2005)} \mathrm{The} \mathrm{decrease} \mathrm{in} \mathrm{the} \mathrm{presynaptic} \mathrm{calcium} \mathrm{current} \mathrm{is} \mathrm{a}$ major cause of short-term depression at a calyx-type synapse. Neuron 46:633-645. 